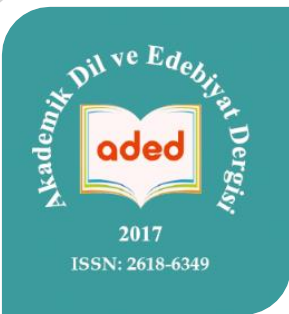

\section{Neşegül BOYBEYI}

Yüksek Lisans Öğrencisi, Mersin Üniversitesi / Türkiye neseboybeyi_3@hotmail.com

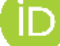

https://orcid.org/0000-0003-3084-3204

\section{Akademik Dil ve Edebiyat Dergisi} Journal of Academic Language and Literature Cilt/Volume: 4, Say1/Issue: 4, Aralık/December 2020

\section{Cahit Sıtkı Tarancı'nın Bilinmeyen İki Hikâyesi Üzerine Bir Değerlendirme}

\author{
Analysis of Two Previously Unknown Stories of \\ Cahit Sitkı Tarancı
}

\author{
Araştırma Makalesi/Research Article \\ Geliş Tarihi/Received: 00.00 .2020 \\ Kabul Tarihi/Accepted: 00.00 .2020 \\ Yayım Tarihi/Published: 00.00.2020
}

Atıf/Citation

Boybeyi, Neşegül (2020). Cahit Sıtkı Tarancı'nın Bilinmeyen İki Hikâyesi Üzerine Bir

Değerlendirme. Akademik Dil ve Edebiyat Dergisi, 4 (4), s. 1126-1139.

DOI: 10.34083/akaded.766718.

Boybeyi, Neşegül (2020). Analysis of Two Previously Unknown Stories of Cahit S1tkı Tarancı.

Journal of Academic Language andLiterature, 4 (4), p. 1126-1139.

DOI: 10.34083 /akaded.766718.

\title{
d
}

https://doi.org/10.34083/akaded.766718

\section{$\checkmark$ iThenticate}

Bu makale iThenticate programıyla taranmıştır.

This article was checked by iThenticate. 


\section{Öz}

Cahit Sıtkı Tarancı 1910-1956 yılları arasında yaşamış, Cumhuriyet Dönemi Türk edebiyatının önde gelen şahsiyetlerinden olmuştur. Şiir alanındaki başarısıyla ünlenmiş olsa da edebiyatçının hikâyeci yönü de bilinmektedir. Hikâyelerini daha çok geçim sıkıntısı nedeniyle kaleme aldığı ve şair yönünün daha güçlü olduğu biliniyorsa da hikâyeleri de oldukça kıymetlidir. Cahit Sıtkı Tarancı; Türk edebiyatında ölüm, yalnızlık, sevgi, aşk, kadın erkek ilişkileri, yaşama sevinci, aile ilişkileri, tabiat gibi temalarıyla bilinmektedir. Şiirlerinde olduğu gibi hikâyelerinde de aynı temalar üzerinde durduğu söylenebilir. Öyle ki şiirleri, hikâyelerinde vücut bulmuş, daha yoğun anlatımla okuyucuya aktarılmaya çalışılmış olarak değerlendirilmiştir. Karşılaştığı zorlukları eserlerine yansıtan yazar, kimi zaman karamsar iken kimi zaman ise yaşama sevincini okurlarına hissettirmiştir. Bu çalışmada ise yazarın hikâyeciliği üzerinde, bilinmeyen iki hikâyesi bağlamında durulacaktır. Yazarın daha önce gün yüzüne çıkartılmamış ve dolayısıyla üzerine çalışılmamış "Aspiratör ve Kaynanamı Yutan Çiçek" adlı iki hikâyesi ele alınacaktır. Cahit Sıtkı'nın bu iki hikâyesi üzerine bir çalışma mevcut olmamakla birlikte ilk defa Yağmurdan Sonra Güneş adlı kitabında derlenmiş, okuyucu ile buluşturulmuştur. Çalışma bu iki hikâyenin bütün yönleriyle ele alınıp incelenmesini kapsayacaktır. İlk kez incelenecek hikâyelerin yapı, tema ve anlatım özellikleri ortaya konarak hikâyeler ayrıntılı bir şekilde irdelenecektir.

Anahtar Kelimeler: Hikâye, Cahit Sıtkı Tarancı, Aspiratör, Kaynanamı Yutan Çiçek, Yağmurdan Sonra Güneş.

\section{Abstract}

Cahit Sitkı Tarancı lived between 1910-1956 and became one of the leading figures of Turkish literature in the Republican Period. Although he's famous for his success in the field of poetry, his storytelling ability is also known. In Turkish literature, his work is known for its themes such as death, loneliness, love, joy of life, relationships, and nature. It can be said that he focuses on the same themes in his stories as in his poems. His poems were embodied in his stories with a more intense narration. Reflecting the difficulties, he faced in life, the writer sometimes felt pessimistic and sometimes joyful. In this study, the storytelling of Cahit Sitkl will be emphasized in the context of two unknown stories. The two stories "Aspiratör and Kaynanamı Yutan Çiçek", which have not been unearthed and therefore not studied, will be discussed. Although there's no study on these two stories of Cahit Sitkl, it was compiled for the first time in his book called "Yağmurdan Sonra Güneş" and was introduced to the reader. The study will cover the handling, analysis and will examine in detail by revealing the structure, theme and narrative features of the stories for the first time.

Keywords: Story, Cahit Sıtkı Tarancı, Aspiratör, Kaynanamı Yutan Çiçek, Yağmurdan sonra Güneş. 


\section{Giriş}

Cahit Sıtkı Taranc1, Cumhuriyet Dönemi Türk edebiyatının önemli şahsiyetlerinden biridir. Özellikle şiirleriyle ilgi gören bir edebiyatçıdır, ancak hikâyeleri de azımsanmayacak kadar değerli ve sayıca çoktur. Yazar, şiirleriyle ön plana çıkmaktadır ve kendi isteği de bu yönde olmuştur. Hikâyeci yönünün bilinmesini istememekle birlikte hikâyelerini ekonomik nedenlerden dolayı kaleme aldığını, kardeşi Nihal'e yazdığg mektubunda belirtmektedir.

Cahit Sıtkı'nın hikâyeleri üzerine birçok çalışma mevcuttur. Selahattin Önerli ve Şaban Sağlık'ın yaptığı çalışmalar buna örnek verilebilir. Yapılan çalışmalarda yazarın şimdiye kadar gazetelerde yayımlanmış 80 hikâyesi üzerine çalışılmıştır. Gün Eksilmesin Penceremden adlı kitabında 43 hikâyesi bir araya getirilmiştir. Son yapılan inceleme ve derlemeyle Necati Tonga tarafından Yağmurdan Sonra Güneş adıyla, yeni bir çalışma yapılmış, 1935-1947 yılları arasındaki 39 hikâyesi bir araya getirilmiş ve ilk kez kitaplaştırılmıştır. Bu incelemeyle birlikte Cahit Sıtkı'nın hikâye sayısının 82 hikâyeye ulaştı̆̆ görülmektedir.

$\mathrm{Bu}$ noktadan hareketle yapılacak olan çalışmada, "Aspiratör ve Kaynanamı Yutan Çiçek” adlı iki hikâye ele alınarak, hikâyelerin yapı, tema ve anlatım özellikleri üstünde durularak aşağıdaki başlıklar altında değerlendirilecektir.

\section{Hikâyeciliği}

Cahit Sıtkı Tarancı, Cumhuriyet Dönemi Türk edebiyatında şiirle ön plana çıkmış bir sanatçıdır. Şair kimliğinin yanı sıra Şaban Sağlık’n da belirttiği gibi birçok farklı edebi kimliği bulunmaktadır. "Cahit Sıtkı’nın edebi kimliği içinde şekillenen 'şairlik', 'deneme yazarlığı', 'mütercimlik' ve 'hikâye yazarlığı' gibi alt kimlikleri vardir." (2003: 71)

Her ne kadar şiir alanındaki başarısıyla tanınmış olsa da gazetelerde yazdığı hikâyeleri de bulunmaktadır. Hikâyelerini daha çok Cumhuriyet gazetesinde yayımladı̆̆ı bilinmekte, bunun yanı sıra farklı yayınlarda da çıktığ "Pek az sayıda olanları da değişik dergilerde yayımlanmıştır. Haber ve Vakit gazetelerinde şairin bazı hikâyeleri çıkmıştır. Bunları da ilk önce Cumhuriyet'te yayımlanmış, daha sonra buradan alınıp başka yerlerde de yayımlanmıştır.” (Sağlık, 2003: 72)

Cahit Sıtkı'nın azımsanmayacak kadar hikâye yazdığı ve tercüme ettiği de bilinen bir gerçektir. Cahit Sıtkı, hikâyelerini geçim sıkıntısı nedeniyle kaleme almış, bunu da kardeşi Nihal'e gönderdiği mektubunda anlatmıştır.

Ne yaparsın para kazanmak için... Yoksa ben ne hikâye yazabilirim ne de roman yazarım dediğim zaman Avrupa hikâyecileri ve romancıları 
gibi yazamayacağımı kastediyorum. Yoksa bizde yazılanların ekserisi kötü şeylerdir. Onlar kadar ben de yazarım ve yazmaktayım da. Fakat imzamı bu gibi yazıların altında görmeyi katiyen istemem. Ya şekerim... Zaten bir adam hem şair hem hikâyeci hem romancı olamaz... İş bölümü her sahada caridir. (Taranc1, 2016: 116)

Yazıp gazeteye gönderdiği hikâyelerinin altına imzasını dahi koymayıp, Cevad Sadık, İrfan Kudret imzalarını kullanmıştır. "Şair, sanat açısından pek bir kıymeti olmadığına inandığı bu hikâyelerin altına gerçek adını değil de takma bir ad koyar. Cahit Sıtkı, imzasının haysiyetini ve şerefini her şeyden üstün tutmakta ve böylesi 'çalakalem' yazılar yazmaktan çekinmektedir.” (Sağlık, 2003: 55)

Kardeşi Nihal'e yazdığı mektubunda da bu durumdan bahsetmiş, konuya Cahit Sıtkı’nın kendisi açıklık getirmiştir. “Şekerim, ağabeyin böyle külüstür yazılar altına imzasını atar mı hiç? Bu yazılar yarım saatte, bir saatte çalakalem yazılmış şeylerdir. Halbuki ben bir mısra üstünde bazen aylarca uğraşan titiz bir sanatkârım." (Tarancı, 2016:116)

Cahit Sıtkı Tarancı kendisini daha çok şair olarak görmekte ve şair olarak anılmak istemektedir. Her ne kadar şair olarak tanınmak ve bilinmek istemiş olsa da yazdığı hikâyeler gün yüzüne çıkarılmış, azımsanmayacak kadar değerli ve sayıca çoktur. Yazarın hikâyelerinin gazetede yayımlanmasının devam etmesi, hikâyelerinin beğenildiğinin ve bu alanda da başarılı olduğunun göstergesidir. Selahattin Önerli’nin sözleri de bu yöndeki düşünceleri destekler niteliktedir.

Yazdıkça açıldı, kuramsal yönden çok iyi bildiği hikâye kurallarını uygulamaya geçince günden güne daha başarılı ürünler vermeye başladı. Öykülerinden birinin, "Mavromatis Efendi”nin, Hüseyin Rahmi Gürpınar’ın dikkatini çekmesi ve yazarı ile tanışmak istemesi bunun kanıtıdır. Yalnız o değil, başka öyküleri de okuyucuların ilgisini üzerine toplamıştır. Hikâyelerinin uzun süre gazetede yayımlanması, okunduğunu, beğenildiğini, ilgi ile izlediklerini gösterir. (Önerli, 1976)

Cahit Sıtkı'nın şiir ve hikâyeleri arasında ilişki vardır. İnci Enginün'nün “Cahit Sıtkı Tarancı'nın Şiir ve Hikâyeleri Arasındaki Benzerlik" başlıklı yazısında belirttikleri de Cahit Sıtkı Tarancı'nın hikâyeleri ve şiirlerinin birbirinden kopuk olmadığını, aksine birbirini tamamlar nitelikte olduğunu göstermektedir.

Şair şahsi yaşantısının ve kültürünün kendisine kazandırdığı birikimi hem hikâyelerinde hem de şiirlerinde işlemiştir. Bazan önce hikâyelerinde işlediklerini, kelimelerin istifinden doğan şiir sesine ulaştıkları zaman şiirine geçirmiş, bazan da şiirini yazdıktan sonra onu bir de hikâyede işleyerek açıklamıştır. Böylece hikâye ve şiirleri birbirini tamamlamıştır. (1991: 240) 
Aynı şekilde Önerli de bu düşünceyi desteklemektedir. O da Cahit Sıtkı’nın şiirlerinde olduğu gibi hikâyelerinde de karamsarlığı ve yaşama bağlıllğ hissettirdiğini söylemektedir; fakat hikâyelerinde yaşama bağlllı̆̆ın daha fazla olduğu yönünde bir değerlendirmede bulunmuştur. "Şiirleriyle hikâyeleri arasında bir bağlantı, bir koşutluk vardır üstelik. Aynı konuyu hem şiirlerinde hem de hikâyelerinde işlemiştir. Şu ayrımla ki, birinde -şiirlerinde- karamsar ve mutsuz gözükürken Tarancı, hikâyelerinde yaşama bağlıdır ve gerçekçidir.” (Önerli, 1976)

Cahit Sıtkı'nın hikâyeciliği üzerinde birçok çalışma yapılmış, hikâyeleri derlenmiş ve kitaplaştırılmıştır. İlk hikâye kitabı Gün Eksilmesin Penceremden adlı kitabında 43 hikâyesi bir araya getirilmiştir.

Sonrasında ise 2019 yilında, Necati Tonga tarafindan yapilan derlemeyle Yağmurdan Sonra Güneş adıyla Cahit Sıtkı Tarancı'nın 39 hikâyesi bir araya getirilmiştir. Cahit Sıtkı Tarancı'nın bilinen 80 hikâyesi üzerine Şaban Sağlık, inceleme yaparak değerlendirmede bulunurken, Halil Kocabaş da yüksek lisans tezinde 80 hikâyeyi derleyerek, değerlendirmede bulunmuştur.

Yapılan derlemelerdeki hikâyeler, 1935-1947 yıllarına aittir. Tonga'nın kitabı sonrasında Cahit Sıtkı'nın bilinen 80 hikâyesinin sayısı 82 hikâyeye çıkmıştır.

Cahit Sıtkı'nın, Tonga'nın çalışmasında yer alan ve daha önce üzerine çalışılmamış iki hikâyesi vardır. Bunlar, Aspiratör ve Kaynanamı Yutan Çiçek adlı hikâyelerdir. Aspiratör, 17 Temmuz 1936 yllında Cumhuriyet gazetesinde, Kaynanamı Yutan Çiçek adlı hikâye ise 10 Mayıs 1938 yılında Yeni Sabah gazetesinde çıkmıştır.

\section{2. "Aspiratör ve Kaynanamı Yutan Çiçek" Adlı İki Hikâyesinin Biçim ve İçerik İncelemesi}

\subsection{Aspiratör}

\subsection{2. Özet}

Afife bir aspiratör yani elektrik süpürgesi almak ister. Kocasının, bu isteği pahalı ve fuzuli bir masraf olarak görebileceği düşüncesiyle Afife, elektrikli süpürgeyi aldırmanın bir yolunu arar. Afife, önce odaları farkında olmadan temizlemeyi unutmuş gibi yapar, sonrasında ise kocasına kendini iyi hissetmediğini ve yorulduğunu anlatır. Her fırsatta temizlik işlerinin kendini çok yorduğunu ima eder. Afife, kocasına bir aspiratör almanın gereksiz masraf olmadığını, aksine ne kadar gerekli olduğunu söyleyerek komşusunun nasıl faydalandığını anlatır. Komşusunun evinin çok temiz olduğunu, çünkü onun bir aspiratör aldığını bu nedenle de evinin temiz kaldığını söyler. Bütün bu düşüncelerine rağmen Afife, kocasına her gördüğü şeyi almak isteyen biri olmadığını, bu kadar pahalı bir aspiratörü alması konusunda 
kocasına ısrarcı davranmayacağını da vurgular. Kocası ise eşinin bu tutumunun hoşuna gittiğini ve ne kadar tutumlu bir eş olduğunu düşündügünü söyleyerek aspiratörün pahalılığı konusunda hemfikir olduğunu dile getirmiştir. Ancak evlerinin büyük olmasından dolayı aspiratörün faydalı olabileceğini söyler. Aksi halde Afife'nin hasta olması durumunda doktor ve ilaçların daha masraflı olabileceğini de düşündügünü bu nedenle de aspiratör alınmasının daha makul bir karar olduğunu ifade eder. Afife, kocasına karşı çıkmayarak söylediklerini onaylar ve hemen bir aspiratör alacağını söyler.

Özeti verilen hikâyenin kişileri şu şekilde değerlendirilebilir:

Hikâyede adı geçen kişi sadece Afife'dir. Bunun yanı sıra kocasından bahsedilmiştir. Hikâyedeki başkişi Afife'dir. Afife genç, güzel bir kadın olduğu kadar kurnazlığıyla da ön plana çıkmaktadır. Afife kurnazlığıyla bilinmenin yanı sıra, antifeminist bir kadındır. "Genç ve güzel Afife, fareyi deliğinden çıkaracak kadar kurnazdı. (...) Afife'nin arkadaşları, hiç değilse evli olanları onun bu kadar antifeminist oluşuna itiraz etmiyor fakat gülüyorlardı." (Taranc1, 2019: 53) ifadeleriyle örnek verilebilir. Afife'nin ne kadar kurnaz olduğu, kocasının ise para harcamayı sevmeyen cimri biri olduğu hikâye edilmektedir. Afife'nin kocasının cimriliğinden dolayı kıyafetlerini eskitinceye kadar giydiği, Afife kadar güzel giyinmeye dikkat eden biri olmadığı anlatılmaktadır. "Daima en fakir, en sünepe bir adam ayarında giyiniyor, elbiselerini tornistan etmek suretiyle iki yüzünü de eskitinceye kadar kullanıyordu." (Taranc1, 2019: 54)

Afife, kocasının aksine güzel giyinen modayı takip eden bir kadındır ve kocası Afife'nin bütün istediklerini almaktadır. Afife'nin kurnazlığının yanı sıra kocası da cimri olduğu kadar kendini zeki zanneden ve eşinin kendi istediği doğrultuda hareket ettiğine inanan biridir. Yazıhanesinde arkadaşıyla kurduğu diyalog buna örnek verilebilir. "Azizim, kadınlar da çocuklar gibi, anlamaya bakmadan itaat etmek için yaratılmışlardır. Evinde rahat etmek mi istiyorsun, sözünü zorla kabul ettirmeye bak. Mesela ben Afife'yle...Ve saire..." (Taranc1, 2019: 57)

Hikâyede Afife’nin kocasının cimriliğinin üstünde durulur; çünkü tek kusuru budur, bunun dişında eşini seven bir kocadır. "Afife'nin kocası sert bir adam değildi hatta fena bir koca da sayılmazdı, üstelik karısını da çok seviyordu. Fakat Afife gibi genç ve güzel bir kadının asla affedemeyeceği bir kusuru vardı: Hasisti." (Tarancı, 2019: 53)

Mekân unsuru ve zaman akışına bakıldığında hikâye, Afife ve kocasının evinde geçmektedir. Ev pek tasvir edilmez. Altı odalı büyük evin işlevi, gelişmelerin mekânı olmasidir.

Hikâyenin geçtiği zamana bakıldığında yarın, ertesi gün şeklinde kurulan 
ifadelerden hareketle, zaman diliminin kısa bir süreyi kapsadığını söylemek mümkündür.

Afife'nin bir elektrikli süpürge almak istemesinden dolayı kocasıyla kurduğu sohbetin birkaç gün boyunca gündeme gelmiş olması ve sonrasında kocasını ikna etmesiyle hikâye sonlanmıştır. Bu ifadelere ve sohbetin sonlandığı ana bakıldığında, hikâyenin yaklaşık üç gün içinde geçtiği söylenebilir.

Yazarın, okuyucuda bırakmak istediği duygu ve düşünce, temanın etkisiyle okuyucuya aktarılmaya çalışılmaktadır. Hikâyede anlatılan ise bir karı koca ilişkisidir.

Karı koca ilişkileri üzerine kurulmuş hikâyede, bu ilişki üzerinden kurnazlık teması işlenir. Afife, kurnazca kocasının cimriliğiyle başa çıkar. Afife'nin kurnazca, kocasını idare etmenin bir usulünü bulduğu, almak istediği aspiratörü de bu usulle aldırdığı hikâyede vurgulanmaktadır.

Evvela odaları temizlemeyi -farkında olmadan yapıyormuş gibi- unuttu ve bir akşam yemeğe oturdukları zaman iniltili bir sesle: 'Ben kendimi iyi hissetmiyorum, altı odalı evimizin temizleme işi beni çok yoruyor. Bugün o kadar takatsizdim ki ancak yatak ve yemek odamızın tozunu alabildim. Biliyorum bana çıkışacak değilsin. Fakat beklenmedik bir ziyaret vaki olursa misafire karşı ne kadar mahcup olacağımı düşünüyorum da. Halbuki komşumuzun evi ne temiz bir görsen! Bugün uğramıştım da... Mis gibi. Fakat bu temizlik komşunun hanımlığından, hamaratlığından ileri gelmiyor. Onun bir aspiratörü var.' (Taranc1, 2019: 55)

cümlelerinden hareketle Afife, kendini iyi hissetmediğini bu nedenle de ev işlerinin aksadığını kocasına vurgulamaktadır. Hikâyenin sonuna doğru ise Afife, elektrikli süpürgenin ne kadar yararlı bir ihtiyaç olduğunu kocasına izah etmiş; fakat maliyetinden ötürü de istemeyeceğini çok da acil olmadığını belirterek, elektrik süpürgesi alması konusunda kocasına ısrarcı davranmayacağını söylemektedir. "Müsterih olabilirsin kocacığım, bu kadar pahalı, taşınması bu kadar zahmetli ve hele bu kadar çok gürültü çıkaran bir aleti satın almanı sana teklif edecek değilim; aklımdan geçmez vallahi..." (Taranc1, 2019: 56)

Afife'nin bu tavırları neticesinde kocası, elektrik süpürgesinin zaruri bir ihtiyaç olduğunu, almaları gerektiğini düşündüğünü söyleyerek, Afife'nin istediği doğrultuda hareket etmiştir.

Benim cici karıcığım, sen makul olduğu kadar da tutumlu bir kadınsın. $\mathrm{Bu}$ sözlerin çok hoşuma gitti. Bununla beraber bir aspiratörün ev içinde yapacağ 1 hizmeti takdir hususunda seninle hemfikir değilim, bilhassa bizim ev gibi altı odalı ev olursa... Evet, belki büyük bir masraftır fakat 
iyi bir aspiratörün ne kadar işimize yarayacağını tahmin ediyor musun? (...) sen de hastalanabilirsin, doktor ve ilaç masrafının bir aspiratörün fiyatından daha fazla tutmayacağı ne malum! Bütün bunlar nazaritibara alınırsa... Hem komşu da bu zarureti duymuştur... (Taranc1, 2019:56)

Afife, kocasının elektrikli süpürge almayacağını bildiğinden dolayı bu durumla da kurnazca nasıl başa çıktığı anlatılmaktadır.

Hikâyenin üzerinde durulması gereken bir diğer unsur olan anlatım özellikleriyle ilgili şu değerlendirmelerde bulunulabilir:

Hikâyede yazar-anlatıcı kullanılmaktadır. Yazar-anlatıcının hâkim olduğu hikâyelerde, yazar olayı aktaran ve nasıl gelişeceğini bilen kişidir. Cahit Sıtkı, Aspiratör adlı hikâyesinde, bu bakış açısını tercih etmiştir. Dolayısıyla hâkim bakış açısıyla olup bitenler aktarılmıştır. "Afife kaç kere kocasına bu giyinişinin içtimai mevkisi ve servetiyle mütenasip olmadığını söylemek istediyse de kocasının iştirak ve münakaşa kabul etmez hâkimiyetini hatırlayarak sustu." (Tarancı, 2019: 54) cümleleriyle örnek verilebilir. Yazar, Afife'nin ne hissettiğini bilen ve gören kişi konumunda olmakla birlikte kişilere ait bilgileri de vermektedir.

Hikâyede Afife ve kocasının durumu anlatılır. Afife'nin kurnazlığı, kocasının cimriliği ve bunun neticesinde durumun nasıl geliştiği anlatılmıştır. Hikâyede kişilere söz hakkı verilerek konuşturulmuştur ve yazar-anlatıcı, araya girerek "Bayan okuyucularımın ketumluklarına güvenerek ve hiçbirisinin bu usulü-zira aynı usulü her tatbik edenin aynı neticeye varması da muhtemeldir-tatbik etmeyeceğine emin olarak, size Afife'nin sırrını faş edecek ve bütün istediklerini nasıl kolayca elde ettiğini anlatacağım." (Tarancı, 2019: 55) cümleleriyle varlığını okuyucuya hissettirmiştir.

Hikâye bir sohbet havası içerisinde Afife ve kocasının anlatımıyla devam etmektedir. $\mathrm{Bu}$ noktada hikâyede Afife ve kocasının diyaloglarına sıkça rastlanmaktadir.

"'Ne dedin?'

'Aspiratör! Elektrik süpürgesi canım.'

'Ya! Acaba komşunun hanımı mirasa mı kondu?'

'yoo... Kocası biriktirdiği parayla almıș.'” (Tarancı, 2019: 55)

ifadeleriyle örnek verilebilir.

Hikâye içinde karı koca ilişkisi anlatıldığı için diyaloglara çokça rastlanır. Hikâyede kısa konuşma dili ağırlıklı cümleler kullanılmaktadır. Oldukça sade ve anlaşılır bir dil kullanılmıştır. 


\subsection{Kaynanamı Yutan Çiçek}

\subsection{1. Özet}

Geminin limana yaklaşmasıyla kahraman-anlatıcının, Şaban Kaptan’a şehre çıkıp çıkmayacağını sormasıyla sohbetleri başlar. Kısa sürede dost oldukları için, Şaban Kaptan yirmi beş sene öncesine dönerek kendi hikâyesini kahraman-anlatıcıya anlatmaya başlar. Marsilyalı bir âlim, ona bitki bilimini öğretir. Bu âlimin çok güzel bir kızı olduğu ve kızını Şaban Kaptan'la evlendirmek istediği anlatılır. Şaban Kaptan'ın da kıza tutkun olduğu söylenir. Şaban Kaptan'ın Refika ile evliliklerinden sonra kayınpederinin fazla yaşamadığı, evliliklerinin üçüncü yılında öldügü belirtilir. Eşi Refika ve kayınvalidesi ile kalan Şaban Kaptan, bir ay sonra da eşini kaybeder. Eşinin ölümünden sonra kayınvalidesiyle birlikte yaşamaya devam eder. Bu arada küçük bir dükkânının olduğu ve onu işleterek geçindiği anlatılır. Kayınvalidesiyle iyi geçinemediği, onun geçimsiz biri olduğu söylenmektedir. Kayınvalidesiyle geçinemediği için de Şaban Kaptan’ın, vaktinin çoğunu vahşi bitkilerini ehlileştirmek için harcadığ 1 anlatır. Özellikle bir çiçeğinden çok bahseder. Çiçeğin zeki olduğu ve çok şey yediği söylenerek, ona obur çiçek ismini verdiği anlatılır. Çiçeğin epeyce büyük olduğu sinek yutabildiği söylenmektedir. Kendisinin ise büyük bir cesaretle obur çiçek adını verdiği bu çiçeğe, fare yutmayı öğrettiğinden bahseder. Hatta çiçeğin bir kedi kadar fare düşkünü olduğu anlatılmaktadır. Bunların dişındaysa Şaban Kaptan'ın, kayınvalidesi ile hiç anlaşamadığından, hayatının artık çekilmez bir hal aldığından bahsedilmiştir. Bu nedenle de onu öldürmeyi tasarladığı anlatır. O kadar canına tak etmiştir ki onu öldürme fikrini fiil haline getirmeyi ve ne şekilde yapması gerektiğini düşünüp bulduğunu söylemiştir. Bu fikrinden sonra, Şaban Kaptan yanına obur çiçeğini de alarak kayınvalidesine gider. Çiçeği kayınvalidesine taktim ederek ne kadar güzel koktuğunu da ilave eder. Kayınvalidesi çiçeği koklamak isterken, çiçeğin alabildiğince açıldığını ve kayınvalidesini nasıl yuttuğunu anlatır.

Kaynanamı Yutan Çiçek adlı hikâyenin kişiler kadrosu şu şekildedir:

Hikâyenin girişinde Şaban Kaptan ve kahraman-anlatıcı vardır. Şaban Kaptan, kahraman-anlatıcıya fantastik bir hikâye anlatmaya başlar. Burada da diğer kişiler ortaya çıkar.

Şaban Kaptan'ın anlattı̆̆ hikâyede bahsi geçen kişiler kadrosunda; Şaban Kaptan, Refika, kayınvalide, Marsilyalı bir alim bulunmaktadır.

Kahraman-anlatıcı, Şaban Kaptan'ı şöyle tanıtmaktadır; "Şaban Kaptan kendisiyle çabucak ahbap olunuveren o hoşsohbet, alçakgönüllü adamlardandı. On beş gün deniz yolculuğu, onun itimadını kazanmaya ve kalbini bana açmaya kâfi gelmişti." (Taranc1, 2019: 87) 
Şaban kaptan, eşi Refika'nın ve kayınpederinin ölümünden sonra kayınvalidesiyle yaşamaktadır. Kayınvalidesini pek sevmeyen, ondan kurtulmak isteyen biridir.

Şaban Kaptan'ın ne iş yaptığına yönelik özellikle değinen bir ifade yoktur; fakat hikâyenin bir gemi içinde sohbetle başlamış olması ve ona kaptan biçiminde hitap edilmesi, mesleğinin kaptan olduğunu belirtir niteliktedir. Şaban Kaptan'ın kendi hikâyesini anlattığı noktada bir dükkânının olduğunu ve bitki tohumları sattığını belirtmektedir.

Refika; Marsilyalı âlimin kızıdır. Şaban Kaptan ile tanışmasına vesile olan babası, Refika'yı Şaban Kaptan'a vermek istemiştir. Refika, Şaban Kaptan'ın severek evlendiği eşidir. Şaban Kaptan, Refika'dan şöyle bahseder; "On altısını süren sarışın, gök gözlü, gayet güzel ve alımlı bir kızı vardı, kızını ben istemeden, kendisi bana verdi. Hoş ben de kıza fena tutkundum, o da ayrı mesele, (...)" (Taranc1, 2019: 87)

Babasının ölümünden sonra, Refika kötü olmaya başlar. Günden güne durumu kötüye giden Refika bir ay sonra hayatını kaybeder. "Refika ve kayınvalideyle yalnız kaldım. Fakat karıma da bir şeyler oluverdi, günden güne solmaya, erimeye başladı. Bir ay içinde onu da topraklara gömdük." (Taranc1, 2019: 88)

Kayınvalideyle ilgili, titiz, sinirli ve geçimsiz olarak bahsedilmektedir. Şaban Kaptan, kayınvalidesi için şu sözleri söylemektedir; "Kaynanayla hangi damat geçinmiş ki ben de geçineyim! İmkânı mı vardı? Her gün kavga ediyorduk, zaten sinirli, titiz, geçimsiz bir acuzeydi." (Taranc1, 2019: 88)

Kayınvalidesini sevmeyen Şaban Kaptan, onu geçimsiz, sinirli biri olarak suçlamış, yok etmenin yollarını aramıştır. Hikâyenin sonunda kayınvalide obur çiçek tarafından yutularak hayatını kaybetmektedir. “(...) obur çiçeğim, birdenbire alabildiğine açıldı ve kaynanamın yüzünü yakaladı. Zavallı kadın çırpındıysa da para etmedi ve benim bir heykel gibi lakayt duruşum, çiçeğin cesaretini ve iştihasını arttırdı, yüzünden sonra başını omuzlarını ve nihayet bütün gövdesini yutuverdi." (Taranc1, 2019: 89)

Marsilyalı bir âlim olarak bahsedilen kişi, aynı zamanda Şaban Kaptan'ın kayınpederidir. Onunla tanışması Şaban Kaptan'a çok şey katmıştır, örneğin Şaban Kaptan bitki bilimini ondan öğrenmiş ve kendi dükkânını işletmiş̦tir. “... baba adamdı, bana nebatat ilminin bütün inceliklerine varıncaya kadar öğretti.” (Tarancı, 2019: 87) şeklinde kayınpederinden bahseder. Şaban Kaptan'ın, eşi Refika ile tanışması da kayınpederi vasıtasıyla olmuştur. Kayınpederinin hayatı, Şaban Kaptan'ın evliliğinden üç ay sonra sona ermiştir. “...bizim kayınpederin ömrü vefa etmedi, evlenmemizden üç ay sonra fertiği çekip öteki dünyayı boyladı. Refika ve kayınvalideyle yalnız kaldım." (Tarancı, 2019: 87) 
Hikâyenin mekân ve zaman unsuruna bakıldığında; hikâyede birden fazla mekânın olduğu söylenebilir. Kahraman-anlatıcının Şaban Kaptan’a geminin limana vardığından bahsettiği ve sohbet ettikleri bölümde bahsi geçen ilk mekân, Batavia Limanıdır. Fantastik hikâye içerisinde geçen bu liman, hayali değildir. Endonezya toprakları içinde yer aldığı ve başkent Cakarta'nın eski ismi olduğu bilinmektedir. "Gemimiz Batavia Limanı'na demirlendiği zaman yerinden kımıldanmayan Şaban Kaptan'a, 'Şehre çıkmayacak mısın?' dedim.” (Tarancı, 2019: 87) cümlelerinden hareketle, geminin bahsi geçen limana demir attığı söylenebilir. Mekânın sadece ismi geçmektedir ve mekâna ait bir tanıtım veya tasvir yapılmamıştır.

Sonraki mekânlar ise, Şaban Kaptan'ın kendi hikâyesini anlatmaya başladığı bölümdür. Şaban Kaptan'ın geçmişe dönerek başından geçenleri anlattığı noktada, küçük bir dükkânının olduğu görülmektedir. "(...) küçük bir dükkânımız vardı, muhtelif nebatların tohumlarını satarak geçiniyorduk. (...) mümkün mertebe dükkândan dışarı çıkmıyor, vahşi nebatlarım ve ehlileştirdiğim çiçeklerimle meşgul oluyordum." (Taranc1, 2019: 88)

Bahsi geçen dükkâna sık sık uğramakta ve bu dükkânda tohum satarak geçimini sağlamaktadır. Dolayısıyla Şaban Kaptan, vaktinin çoğunu bu mekânda geçirmektedir. Bunun yanı sıra, "Nihayet bir gece yatağımda sağa sola dönüp uyumaya çalışırken birdenbire kafamda bir fikir peyda oldu, bu fikir aydınlığında sevincimden içim içime sığmıyordu. Bu keyifle uykuya geçtim.” (Tarancı, 2019: 88) ifadesinden hareketle mekânlardan birinin de ev olduğu söylenebilir. Benzer şekilde Şaban Kaptan, çiçeğini alıp kayınvalidesinin odasına götürmesi, çiçeği masaya bırakması hikâyenin ev ve dükkân ortamında geçtiğini göstermektedir. "Kollarımda çiçekle kaynanamın odasına girdim. (...) Saksıyı masanın üzerine bırakmıştım. Ve kaynanam oturduğu koltuktan bakıyordu." (Taranc1, 2019: 89)

Hikâyede an ve geçmiş olmak üzere iki ayrı zaman dilimi vardır. Birincisi Şaban Kaptan ile Kahraman-anlatıcının konuştuğu kısımdır. Bu kısım yaklaşık 15-20 dakika sürmektedir. İkincisi bu sohbet içerisinde geçmişe dönülmesiyle ortaya çıar. Şaban Kaptan, yirmi beş yıl öncesine dönerek fantastik bir hikâye anlatır. Dolayısıyla hikâyede an ve geçmişten oluşan, yirmi beş yıla yayılan bir zaman dilimi olduğu söylenebilir. Olay zamanı 15-20 dakika, anlatılan zaman yirmi beş senedir.

Hikâye tema unsuru açısından dikkate alındığında, hikâyenin fantastik ögeler barındırdığı görülmektedir. Bu noktadan hareketle Kaynanamı Yutan Çiçek, fantastik bir hikâye örneğidir. Hikâyenin fantastik boyutu ise, Şaban Kaptan'ın obur çiçek olarak adlandırdığı çiçeğine sinek hatta fare yutturmasını öğretmesiyle

\footnotetext{
${ }^{1}$ https://tr.wikipedia.org/wiki/Cakarta
} 
başlamaktadır. “(...) Bir at gibi zekiydi, her şeyi anlıyordu ve çok şey yiyordu. Ben ona obur çiçek adını takmışım. Yanına yaklaşan sinekleri hemen yutuveriyordu." (Taranc1, 2019: 88) ifadeleri buna örnektir.

Şaban Kaptan, kayınvalidesiyle anlaşamayan bir damattır ve ondan kurtulmak istemektedir. Bu noktada obur çiçek adını verdiği çiçeğin; sinek hatta fare yutabiliyor olması, Şaban Kaptan'a kayınvalidesinin de bu çiçek tarafından yutulabileceği fikrini vermiştir. Bu düşünce çerçevesinde şekillenen hikâye fantastik ögelerin artmasına zemin hazırlamıştır.

Fakat bir kere aklıma koymuştum ya, çiçeği masanın üzerinden alarak kaynanama götürdüm, 'çok güzel kokar!' dedim. Kadıncağız koklamak için eğilip yüzünü yaklaştırdı ve o zaman dostum, çiçeğim, obur çiçeğim, birdenbire alabildiğine açıldı ve kaynanamın yüzünü yakaladı. Zavallı kadın çırpındıysa da para etmedi ve benim bir heykel gibi lakayt duruşum, çiçeğin cesaretini ve iştihasını arttırdı, yüzünden sonra başını omuzlarını ve nihayet bütün gövdesini yutuverdi. (Taranc1, 2019: 89)

cümleleriyle fantastik ögelere örnek verilebilir.

Şaban Kaptan'ın mübalağa dolu anlatımından sonra kahraman-anlatıcının, söze girerek Şaban Kaptan'ın anlattığı hikâyesinin bir kurgu olduğunu, inanmadığını belirtmesi de bahsi geçen hikâyenin fantastik hikâye örneği olduğunu kanıtlar niteliktedir. 'Biraz düşündükten sonra, 'Bana baksana Şaban Kaptan,' dedim, 'Senin obur çiçek anlattığın bu hikâyeyi yutar mıydı dersin?’” (Tarancı, 2019: 89) ifadeleriyle örnek verilebilir. Bu metin, doğrudan mesaj vermeye çalışmayan dolayısıyla fantastik tarzda kurgulanmış bir hikâyedir.

Hikâyenin anlatım özellikleriyle ilgili olarak şu değerlendirmelerde bulunulabilir:

Hikâyede kahraman-anlatıcı kullanılmaktadır. Bu kahraman anlatıcı anın anlatıldığ 1 yerde ismi verilmeyen kişi, geçmişin anlatıldığı yerde Şaban Kaptan'dır.

Hikâye sohbetle başlamaktadır. Sohbeti aktaran kişi adı verilmeyen kişidir. Daha sonra Şaban Kaptan fantastik hikâyeyi anlatmaya başlar ve anlatıcı Şaban Kaptan olur.

Anlatımın yaklaşık olarak 15-20 dakika içerisinde geçtiği düşünülürse, anlatım ilk olarak bulunulan andan başlayıp geçmişe dönmüş ve yeniden ana dönülerek sonlanmıştır. Bu noktadan hareketle çerçeve hikâye denebilecek, iç içe geçmiş bir hikâyenin varlığından bahsedilebilir.

Hikâyenin dili, süsten uzak sade bir dille kaleme alınmıştır. Sohbetle geçen hikâye içerisinde diyalog ve tasvire yer verilmiştir: 
Hikâyesinin burasında Şaban Kaptan'ın sesi kısıldı, çok heyecanlandı, ayağa kalkt1.

Ben, 'Ya çiçek ne oldu?' dedim.

'Yedi-sekiz ay kadar yaşadı. Harikulade bir çiçekti, her şeyi yutuyordu.'

Biraz düşündükten sonra, 'Bana baksana Şaban Kaptan,' dedim, 'senin obur çiçek anlattığın bu hikâyeyi yutar mıydı dersin?'

Piposundan bol bol bir nefes savurarak, 'Bunu ben bilmem!' dedi. (Taranc1, 2019:89)

ifadeleri hikâyenin sade bir dille kaleme alınmış olmasına ve diyaloğa örnek verilebilir. "Sırası gelmişken söyleyeyim, gayet büyük bir çiçekti ve uzun, kalın bir sakı vardı. İlk zamanlarda tüveyçleri kapanırken ancak sinek yutabiliyordu; fakat..." (Taranc1, 2019: 89) ifadeleri tasvire örnek verilebilir.

\section{Sonuç}

Cahit Sıtkı'nın edebi hayatına şiirle girmesi ve şair yönüyle tanınmak istemesi, hikâyelerini ve hikâyecilik yönünü gölgede bırakmıştır. Şair yönünü korumaya gayret eden Cahit Sıtkı, bu nedenledir ki hikâyelerinde Cevad Sadık ve İrfan Kudret takma isimlerini kullanmıştır. Hikâyeleri üzerine yapılan çeşitli çalışmalar, Cahit Sıtkı'nın hikâyeciliğinin şair yönünden ayrılmayacağını, aksine bir bütün olarak değerlendirilmesi gerektiğini belirtmiştir. Yapılan çalışmalar, Cahit Sıtkı'nın yıllarca okuyucuya yabancı kalan hikâyecilik yönünün, en az şair yönü kadar kıymetli olduğunu okuyucuya sunmuştur. Çalışma Cahit Sıtkı'nın daha önce üzerine çalışılmamış iki hikâyesini ele alarak, hikâyelerin yapı, tema ve anlatım özellikleri üzerinde durmuştur. Buradan hareketle denilebilir ki; Cahit Sitkı, Aspiratör adlı hikâyesinde günlük yaşamda yaşanan bir olayı hikâyesine konu ederken, Kaynanamı Yutan Çiçek adlı hikâyesinde fantastik unsurlardan yararlanmıştır. Aspiratör adlı hikâyesinde, Afife ve kocasının yaşadıkları, günlük hayatta yaşanabilecek bir karı kocanın durumuyken, Kaynanamı Yutan Çiçek adlı hikâyesinde de Şaban Kaptan'ın başından geçen bir olayı mübalağa sanatını kullanarak, fantastik bir hikâye tadında anlatımını konu etmektedir. Bu hikâyedeki estetik unsurun başında kurgu gelmiştir ve bu kurgunun da fantastik öge üzerinde kurgulandığı görülmektedir. Her iki hikâyede de kişi kadrosunun çok kalabalık olduğu söylenemez. Benzer şekilde her iki hikâyede, zaman unsurunun da kısa bir süreyi kapsadığı görülmektedir. Anlatım tekniğinde diyalog ve tasvire yer verirken, zaman unsurunda geçmişe dönüşler vardır. Hikâyede, süsten uzak sade bir dil tercih edilmiştir. Bu hatlarıyla, genel olarak denebilir ki Cahit Sıtkı, genel çerçevenin dışına çıkmamıştır. Çalışmada bahsi geçen iki hikâyesi de diğer 80 hikâyesiyle benzer özellikler göstermektedir. 


\section{Kaynakça}

Enginün, İnci (1991). Yeni Türk Edebiyatı Araştırmaları. İstanbul: Dergâh Yayınları. Kocabaş, Halil (1994). Cahit Sıtkı Tarancinın Hikâyelerinin Derlenmesi ve Değerlendirilmesi. Yüksek Lisans Tezi, Dicle Üniversitesi Sosyal Bilimler Enstitüsü, Diyarbakır.

Okur, Enver (1993). Cahit Sitkı Tarancı Hayatı, Eserleri, Sanatı. Doktora Tezi, Ondokuz Mayıs Üniversitesi Sosyal Bilimler Enstitüsü, Samsun.

Önerli, Selahattin (1976). Cahit Sıtkı Tarancı'nın Hikâyeciliği ve Hikâyeleri. Ankara: Akran Matbaacilik.

Sağlık, Şaban (2003). Cahit Sıtkı Tarancı'nın Hikâyeleri Üzerine Bir İnceleme. Ankara: Hece Yayınları.

Tarancı, Cahit Sıtkı (1995). Yazılar, Makaleler, Konuşmalar, Yanıtlar. Sazyek, Hakan (hzl.) İstanbul: Can Yayınları.

Tarancı, Cahit Sttkı (2016). Evime ve Nihal'e Mektuplar. Enginün, İnci (hzl.) İstanbul: Can Yayınları.

Taranc1, Cahit Sıtkı (2019). Yağmurdan Sonra Güneş. Tonga, Necati (hzl.) İstanbul: Can Yayınları.

Tonga, Necati (2019). Cahit Sitki'dan 84 Yillık Hikâyeler. https://www.karar.com/hayat-haberleri/cahit-sitkidan-84-yillik-hikayeler1264362

Uyguner, Muzaffer (1992). Cahit Sıtkı Tarancı Yaşamı, Sanatı, Yapıtlarından Seçmeler. Ankara: Bilgi Yayınevi.

Yetiştiren, Nuri (2014). Cahit Sıtkı Tarancı'nın Ölüm Konulu Şiirlerine Psikolojik Bir Bakış. Yüksek Lisans Tezi, Dumlupınar Üniversitesi Sosyal Bilimler Enstitüsü, Kütahya.

Zariç, Mahfuz (2013). Cahit Sıtkı Tarancı'nın Şiirlerinde ve Öykülerinde İmgeler, Üslup ve Tematik İlgiler. Dicle Üniversitesi Sosyal Bilimler Enstitüsü Dergisi, Cilt.5, S.10, 22-39. 